\title{
Structure and Properties of the San Andreas Fault in Central California: Recent Results from the SAFOD Experiment
}

by Stephen Hickman, Mark Zoback, William Ellsworth, Naomi Boness,

doi:10.2204/iodp.sd.s01.39.2007

Peter Malin, Steven Roecker, and Clifford Thurber

The San Andreas Fault Observatory at Depth (SAFOD) is a $3.2-\mathrm{km}$-deep borehole observatory drilled into the San Andreas fault zone at seismogenic depths to study directly the physical and chemical processes controlling faulting and earthquake generation. SAFOD forms one component of EarthScope, a major Earth Science facility program of the U.S. National Science Foundation; the other two funded components are U.S. Array, a continental-scale seismic network, and the Plate Boundary Observatory, an extensive network of GPS receivers and strainmeters deployed across the western U.S. SAFOD is being conducted in collaboration with the U.S. Geological Survey and the International Continental Scientific Drilling Program (ICDP). A detailed scientific rationale for drilling into active faults (including an overview of past and ongoing fault zone drilling projects) is presented in Zoback et al. (2007).

SAFOD is located in centralCalifornia within the transition between the creeping and locked sections of the San Andreas Fault, $9 \mathrm{~km} \mathrm{NW}$ of Parkfield, Calif. and just NW of the rupture zone of the 2004 M6.0 Parkfield earthquake. The fault displays a range of behaviors at this site. At the surface, it is creeping at a rate of $1.8 \mathrm{~cm} \mathrm{yr}^{1}$, with most of the fault displacement localized to a zone no more than $10 \mathrm{~m}$ wide (Burford and Harsh, 1980; Schulz, 1989). Numerous earthquakes occur directly on the San Andreas fault at this location, and they define the fault to be a narrow, near-vertical seismically active zone with a top at about $3-\mathrm{km}$ depth (Fig. 1).

An important feature of microearthquakes along the San Andreas fault at SAFOD is that they occur in families of repeating events. The University of California - Berkeley High Resolution Seismic Network has observed individual earthquakes to recur every few years at precisely the same location and with the same magnitude (Nadeau and McEvilly, 1997; Nadeau et al., 2004). Repeating sources of up to M2 are located at depths as shallow as $3 \mathrm{~km}$ at the SAFOD site, and they play a key role in guiding SAFOD drilling.

In preparation for drilling of the main SAFOD borehole, a 2.2-km-deep vertical pilot hole was funded by the ICDP and rotary drilled in 2002 at the SAFOD site, located $1.8 \mathrm{~km}$ to the southwest of the surface trace of the San Andreas fault (Fig. 2). Results from the pilot hole were instrumental in defining the background geological and geophysical setting of the fault at this location, and in providing information on geologic structure and earthquake locations needed for planning of the main SAFOD experiment. Results from the SAFOD Pilot Hole and related site characterization studies were presented by Hickman et al. (2004) and in associated papers published in two special issues of Geophysical Research Letters.

During Phases 1 and 2 in the summers of 2004 and 2005, the SAFOD main hole was rotary drilled vertically and then deviated across the entire San Andreas fault zone through the zone of repeating microearthquakes, passing beneath the surface trace of the San Andreas fault at a depth of $3.1 \mathrm{~km}$ (Fig. 2C). From its inception, a major goal of SAFOD has been to drill into, sample, and monitor one or more of the repeating M2 earthquake sources (green, red, and blue earthquakes in Figs. 1 and 2) to follow the buildup and release of strain through multiple earthquake cycles.

Extensive drill cuttings were obtained during Phases 1 and 2, and a real-time analysis of gases in the drilling mud was carried out (Wiersberg and Erzinger, 2007 a, b). In addition, about sixty meters of spot core was acquired from the SAFOD main borehole at vertical depths of $1.5 \mathrm{~km}, 2.5$ $\mathrm{km}$, and $3.2 \mathrm{~km}$, and sidewall cores were collected in the lower section of the hole. An extensive suite of open-hole

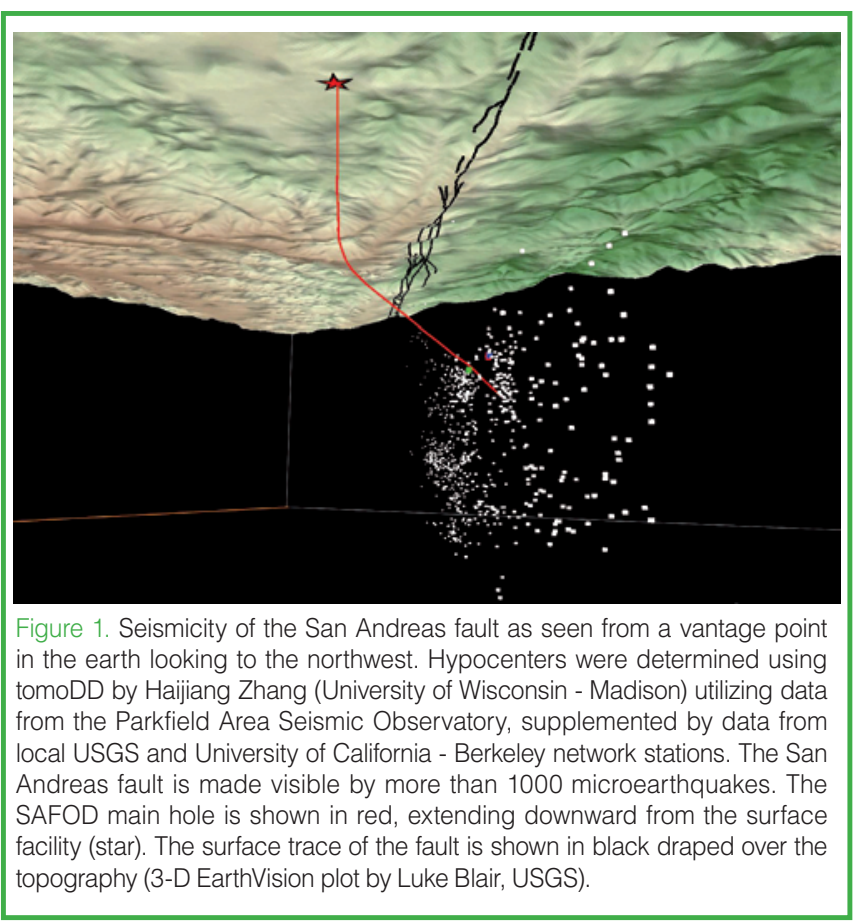


geophysical logs was obtained along almost the entire length of the well. For a complete description of drill cuttings, core samples and geophysical $\log$ s acquired during SAFOD Phases 1 and 2 see the ICDP Web site on SAFOD, link to Public Data (safod.icdp-online.org). Preliminary results from SAFOD Phases 1 and 2 were presented in two special sessions of the December 2005 American Geophysical Union meeting, and numerous publications are in print or under review detailing early results from SAFOD. Results from analyses of drill cuttings and cores from SAFOD are discussed in Solum et al. (2007), Schleicher et al. (2007), and references cited therein.

Four major geologic units were encountered along the trajectory of the SAFOD main hole. In the vertical section of the wellbore, the near-surface Quaternary and Tertiary sediments were found to be underlain by Salinian granite at a depth of $\sim 700 \mathrm{~m}$. After the borehole was deviated toward the fault, arkosic sediments (most likely locally-derived from Salinian granite) were encountered about $300 \mathrm{~m} \mathrm{NE}$ of the drill site, perhaps after crossing the Buzzard Canyon fault, a $\mathrm{NW}$-trending strike-slip fault exposed at the surface that trends sub-parallel to the San Andreas (M. Rymer, personal comm.). Approximately $1200 \mathrm{~m}$ NE of the drill site, a possibly ancestral trace of the San Andreas was crossed as the lithology changed abruptly to claystones and siltstones of the Great Valley Formation, found throughout central California on the east side of the San Andreas.
Geophysical logs and cuttings analysis indicate that the San Andreas fault is a zone of anomalously low P-and S-wave velocity and resistivity that defines a relatively broad ( 200-m-wide) damage zone (Fig. 3). The location of a currently active trace of the San Andreas fault is revealed by casing deformation (indicated by the red line in Fig. 3) detected through repeated multifinger caliper logs. This active fault is associated with a narrower ( 30 -m-wide), more highly localized zone of low P- and S-wave velocity and resistivity embedded within the broader damage zone. Serpentinites and talc were also found in cuttings immediately adjacent to this deforming zone (Moore and Rymer, 2007; Solum et al., 2006, 2007), which might be responsible for the predominantly creeping behavior of the San Andreas fault at this location as well as its low long-term strength. Work is now underway to determine if this actively deforming fault trace is associated with repeating microearthquakes in the SAFOD target region.

Stress measurements in the SAFOD pilot hole and main hole provide strong evidence in support of the hypothesis that the San Andreas is a weak fault imbedded in an otherwise strong crust. Horizontal differential stress magnitudes in the pilot hole were found to be high adjacent to the fault, while the orientation of maximum horizontal stress at depth in the hole indicates low levels of shear stress resolved onto the fault itself (Hickman and Zoback, 2004). Shear-wave anisotropy measurements in the SAFOD main hole further indicate that the direction of maximum horizontal compression remains nearly perpendicular to the fault to

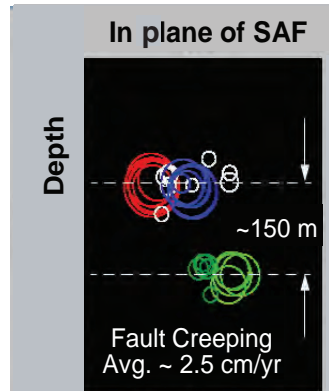

[B] Distance Along Strike

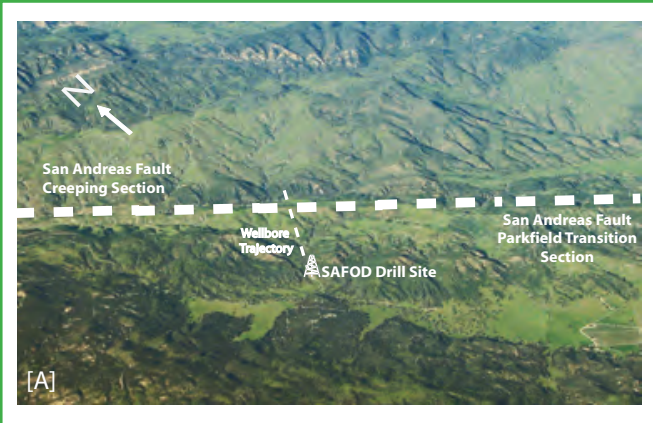

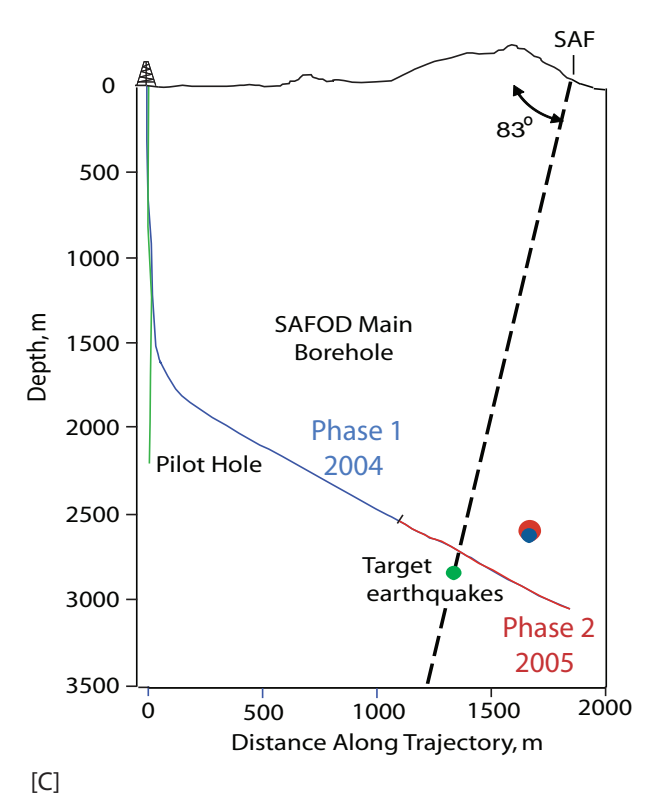

$[C]$ within a few hundred meters of the active fault trace at depth (Boness and Zoback, 2006). In addition, heat flow measurements in the SAFOD pilot hole and main hole (to $3.1 \mathrm{~km}$ depth) are consistent with shallower data in the region which show no evidence of frictionally-generated heat (Williams et al., 2004; 2006).

Beginning in February 2006 , we conducted a series of instrumental investigations in the SAFOD main hole in close proximity to where fault movement is actively deforming the borehole casing. A digitally telemetered pair of 3-component $15-\mathrm{Hz}$ geophones was mechanically clamped inside the casing to record very local earthquakes at a sample rate of $4000 \mathrm{sps}$. The tool also contains a biaxial tiltmeter. We succeeded in 


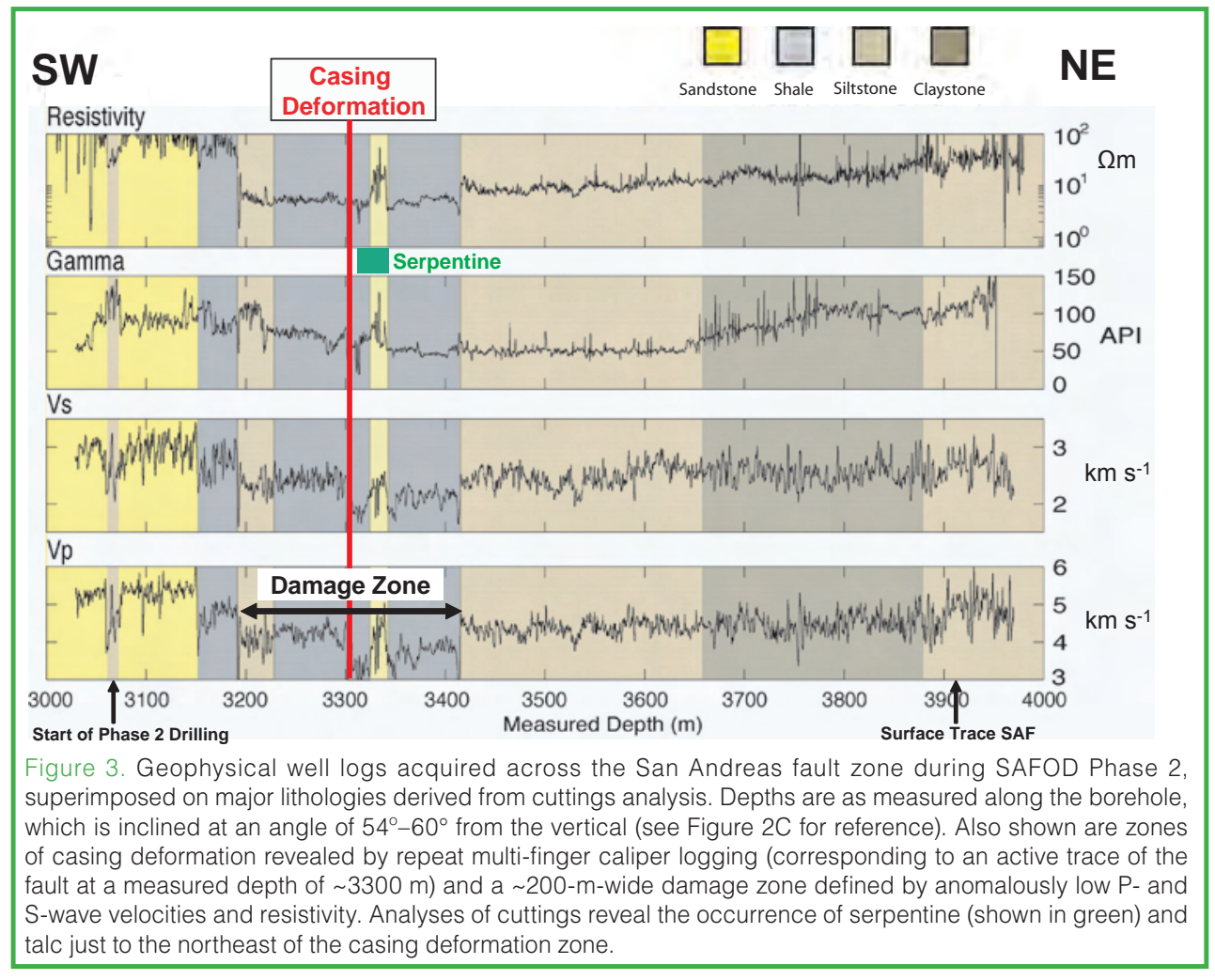

quakes for long-term monitoring of near-field radiated seismic energy, deformation, fluid pressure, and seismicity through multiple earthquake cycles (Fig. 4). This will allow scientists to test-for the very first time-a variety of hypotheses related to earthquake rupture nucleation, propagation, and arrest, as well as the possible role of fluid pressure in controlling fault strength and earthquake periodicity.

\section{References}

Boness, N. and Zoback, M.D., 2006. A multi-scale study of the mechanisms controlling shear velocity anisotropy in the San Andreas Fault Observatory at Depth. Geophysics, 7(5):F131-F146, doi:10.1190/1.2231107.

Burford, R.O., and Harsh, P.W., 1980. Slip on the San Andreas fault in central

recording a wide variety of seismic phenomena with this instrumentation, which are discussed in more detail by Ellsworth et al (2007). Notably, several of the M2 target earthquakes were recorded in the very near-field, at distances down to $\sim 400 \mathrm{~m}$. SAFOD downhole seismometers also recorded a new type of seismic wave that arrives between the P- and S-waves and appears to be a "leaky mode" PSV fault guided wave; the well known SH-type fault guided waves were also seen. If borne out by more complete modeling, these observations provide strong support for the hypothesis that continuous narrow, low-velocity fault zones extend deep into the seismogenic crust. We also successfully conducted several "virtual earthquake" experiments in which small explosive charges were detonated next to surface seismograph stations to measure the travel time from the station to the borehole seismometer. Using travel time reciprocity, these data are being used to determine with greater accuracy the absolute locations of the SAFOD target earthquakes in preparation for Phase 3 .

During Phase 3 of SAFOD, planned for the summer of 2007, continuous cores will be acquired from three multilateral holes branching off the main SAFOD borehole to directly sample the damage zone (Fig. 3) and both the creeping and seismically active faults at depth (Fig. 2B). These core samples will be extensively studied in the laboratory to compare and contrast the composition, deformation mechanisms, physical properties, and rheological behavior of creeping and seismogenic fault rocks at realistic in situ conditions. At the conclusion of SAFOD Phase 3, an array of instruments will be deployed in the cased borehole in the immediate vicinity of the repeating M2 target earth-
California from alinement array surveys. Bull. Seismol. Soc. Am., 70:1233-1261.

Ellsworth, W., Malin, P.E., Imanishi, K., Roecker, S.W., Nadeau, R., Oye, V., Thurber, C.H., Waldhauser, F., Boness, N.N., Hickman, S.H., and Zoback, M.D., 2007. Seismology inside the fault zone: applications to fault-zone properties and rupture dynamics. Scientific Drilling Special Issue, 1:85-88.

Hickman, S. and Zoback, M.D., 2004. Stress measurements in the SAFOD pilot hole: implications for the frictional strength of the San Andreas Fault. Geophys. Res. Lett., 31:L15S12.

Hickman, S., Zoback, M.D., and Ellsworth, W.E., 2004. Introduction to special section: Preparing for the San Andreas Fault Observatory at Depth. Geophys. Res. Letters,. 31, L12S01, doi:10.1029/20040GL20688.

Moore, D.E. and Rymer, M.J. , 2007, Talc-bearing serpentinite and the creeping section of the San Andreas fault. Nature 448, 795-797, doi:10.1038/nature06064

Nadeau, R.M. and McEvilly, T.V., 1997. Seismological studies at Parkfield V: Characteristic microearthquake sequences as fault-zone drilling targets. Bull. Seismol. Soc. Am., 87:1463-1472.

Nadeau, R.M., Michelini, A., Uhrhammer, R.A., Dolenc, D., and McEvilly, T.V., 2004. Detailed kinematics, structure and recurrence of micro-seismicity in the SAFOD target region. Geophys. Res. Lett., 31:L12S08, doi:10.1029/2003GL019409.

Schleicher, A.M., van der Pluijm, B.A., Warr, L.N., and Solum, J.G., 2007. Electron Microscopy of Clay Minerals in Mudrocks from the San Andreas Fault Observatory at Depth (SAFOD). Scientific Drilling Special Issue 1:68-70.

Schulz, S.S., 1989. Catalog of creepmeter measurements in California from 1966 through 1988. U.S. Geological Survey Open-File Report 89-650.

Solum, J.G., Hickman, S.H., Lockner, D.A., Moore, D.E., van der 


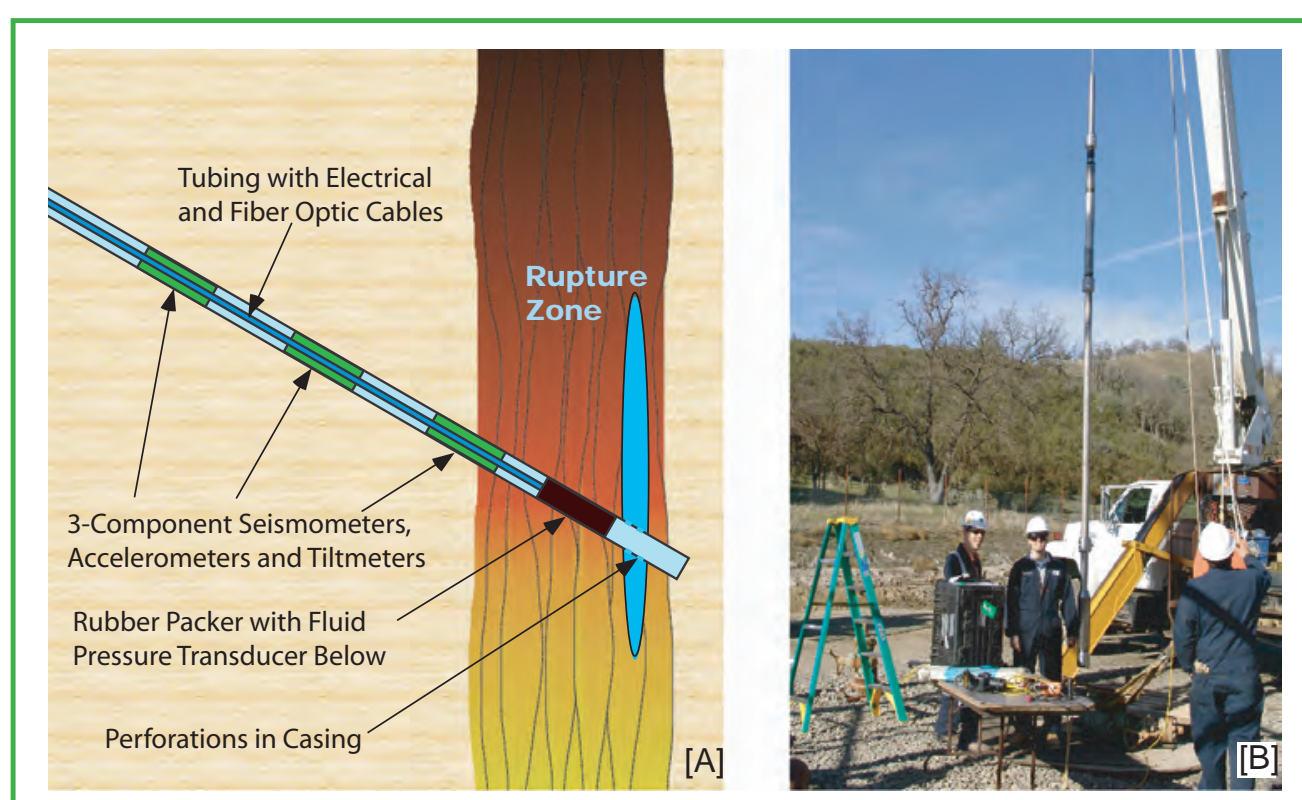

Figure 4. [A] Schematic of the long-term monitoring array for SAFOD. After casing is cemented in place from the bottom of corehole 3 to the surface (see Fig. 2B), the casing will be perforated in the fault zone, and the array will be emplaced on rigid tubing close to the target earthquake rupture zone. This array is designed so that it can be periodically removed for maintenance and repair. Unidirectional bow-springs (not shown) decentralize the seismic sensors to insure good coupling with the casing, and a rubber packer is inflated just above the perforations to monitor variations in fluid pressure during the earthquake cycle. [B] Engineers from Pinnacle Technologies testing a prototype for the seismic and tilt sensors in the SAFOD borehole following Phase 2 drilling. Photo taken by Peter Malin.
Pluijm, B.A., Schleicher, A.M., and Evans, J.P., 2006. Mineralogical characterization of protolith and fault rocks from the SAFOD main hole. Geophys. Res. Lett., 33:L21314, doi: 10.1029/2006GL027285.

Solum, J.G., Hickman, S., Lockner, D.A., Tembe, S., Evans, J.P., Draper, S.D., Barton, D.C., Kirschner, D.L., Chester, J.S., Chester, F.M., van der Pluijm, B.A., Schleicher, A.M., Moore, D.E., Morrow, C., Bradbury, K., Calvin, W.M., and Wong, T.-F., 2007. San Andreas fault zone mineralogy, geochemistry and physical properties from SAFOD cuttings and core. Scientific Drilling Special Issue 1:64-67.

Wiersberg, T. and Erzinger, J., 2007a. A helium isotope cross-section study through the San Andreas Fault at seismogenic depths. Geochem. Geophys. Geosyst., 8(1):Q01002, doi:10.1029/ 2006GC001388.

Wiersberg, T. and Erzinger, J., 2007b. Real-time mud gas monitoring: A technique to obtain information on the composition and distribution of gases at depth while drilling. Scientific Drilling Special Issue 1:71-72.

Williams, C.F., Grubb, F.V., and Galanis, S.P., 2004. Heat flow in the SAFOD pilot hole and implications for the strength of the San Andreas Fault. Geophys. Res. Lett., 31:L15S14, doi:10.1029/2003GL019352

Williams, C.F., Grubb, F.V., and Galanis, Jr, S.P., 2006. Heat flow measurements across the San Andreas Fault near Parkfield, California - preliminary results from SAFOD. Eos Trans. $A G U, 87(52)$, Fall Meet. Suppl., Abstract S33B-0241.

Zoback, M.D., Hickman, S., and Ellsworth, W., 2007. The role of fault zone drilling. In Kanamori, H., and Schubert, G. (Eds.), Earthquake Seismology - Treatise on Geophysics. Amsterdam (Elsevier), in press.

\section{Related Web Link}

safod.icdp-online.org

\section{Authors}

Stephen Hickman, U.S. Geological Survey, 345 Middlefield Road, Mail Stop 977, Menlo Park, Calif., 94025, U.S.A., e-mail:hickman@usgs. gov.

Mark Zoback, Stanford University, Mitchell Building, Room 359, Stanford, Calif., 94305-2215, U.S.A.

William Ellsworth, U.S. Geological Survey, 345 Middlefield Road, Mail Stop 977, Menlo Park, Calif., 94025, U.S.A.

Naomi Boness, Chevron Energy Technology Company, 6001 Bollinger Canyon Road, San Ramon, Calif., 94583,

\section{U.S.A.}

Peter Malin, Duke University, 109A Old Chem, Box 90227, Durham, N.C., 27708, U.S.A.

Steven Roecker, Department of Earth and Environmental Sciences, Rensselaer Polytechnic Institute, Troy, N.Y., 12180, U.S.A.

Clifford Thurber, Department of Geology and Geophysics, University of Wisconsin, 1215 West Dayton Street, Madison, Wis., 53706, U.S.A. 